\title{
Comparison of WhatsApp and Google Classroom Group Online Learning Models to Student Learning Outcomes
}

\author{
Eka Susilowati \\ Universitas PGRI Adi Buana Surabaya \\ eka_s@unipasby.ac.id
}

Received: November 2020; Accepted: December 2020; Published: January 2021

\begin{abstract}
The purpose of this study was to compare whether there were differences in the learning outcomes of students in the Mathematics Education Study Program of the University of PGRI Adi Buana University Surabaya in the even semester of the 2019/2020 academic year in Calculus I when applying the online learning model using the WhatsApp group and using Google Class and to know which online learning model is better between the two. The research methods used in analyzing this research are using a quantitative research approach. The type of research used is a quasiexperimental research design, namely a posttest only comparison group design. The sampling technique was applied. is a simple random sampling technique where the population is 90 students and the sample used is 45 students from classes $2019 \mathrm{~A}$ and $2019 \mathrm{C}$. The data used in this study are sourced from primary data, namely the scores of the 2019A class and class students' Middle Semester Examination. $2019 \mathrm{C}$ and secondary data derived from observations and archives. The data analysis technique used was descriptive data analysis and inferential statistical analysis through a t-test using the MS Excel program. Based on the results of the research and discussion, it can be concluded that the online learning model using WhatsApp Groups is slightly better than using Google Classroom by paying attention to the system that is applied during learning.
\end{abstract}

Keywords: covid 19, WhatsApp group, google classroom, daring learning model, comparison.

How to Cite: Susilowati, E. (2021). Comparison of WhatsApp and Google Classroom Group Online Learning Models to Student Learning Outcomes. Journal of Medives: Journal of Mathematics Education IKIP Veteran Semarang, 5(1), 61-73. 


\section{PENDAHULUAN}

Pandemi Covid 19 mulai masuk di Indonesia sejak bulan Januari 2020. Pada waktu itu, masih belum terasa dampak yang signifikan akibat virus Covid 19 ini. Namun, lama kelamaan tepatnya bulan April 2020, sudah sangat terasa dampak negatif pandemik ini. Dampak tersebut terasa dengan semakin meningkatnya pasien yang positif Covid 19 dan disusul banyaknya yang meninggal. Virus ini bisa dibilang berbahaya karena proses penularannya dari manusia ke manusia, meskipun virus ini berasal dari kelelawar di Wuhan China. Akibat penularan yang terjadi antar manusia ini, mengakibatkan kita harus membatasi interaksi dengan sesama. Dengan demikian, banyak lini kehidupan yang berubah total, salah satunya adalah ranah pendidikan. Proses pembelajaran yang sebelumnya berlangsung tatap muka, berubah menjadi pembelajaran daring demi mengurangi interaksi antar manusia. Proses pembelajaran matematika di tingkat perguruan tinggi pun akhirnya dilakukan secara daring sebagaimana dengan pembelajaran matematika yang dilakukan di jenjang sekolah di bawahnya. Di sekolah dasar dan menengah biasanya pembelajaran hanya terpusat pada pendidik. Hal tersebut sudah diungkapkan oleh (Amijaya, Ramdani, \& Merta, 2018) yang mengakibatkan siswa cenderung tidak aktif dan hanya mengandalkan pada materi yang bersumber dari apa yang telah diutarakan oleh pendidik (guru/dosen) dengan tidak mengembangkannya sendiri. Hal tersebut haruslah diubah demi meningkatkan mutu pendidikan. Dengan demikian, meskipun proses pembelajaran daring tetap diusahakan dipusatkan kepada keaktifan mahasiswa.

Untuk mewujudkan keaktifan peserta didik, dalam hal ini pada semua pembelajaran luring dan daring, pendidik mempunyai peranan sangat penting. Selain itu, pendidik juga berperan untuk mengatasi miskonsepsi yang terjadi pada siswa (Sutiarso, Coesamin, \& Nurhanurawati, 2018). Miskonsepsi siswa ini juga pernah diteliti oleh (Kazemi \& Ghoraishi, 2012) pada saat membandingkan model pembelajaran Problem Based Learning dengan yang konvensional. Pembelajaran berpusat pada dosen pun sempat diteliti oleh (Simorangkir, 2018) dengan membandingkan keefektifannya dengan model pembelajaran jigsaw. Selain itu, ada juga (Harianto, Rusijiono, Masitoh, \& Setyawan, 2020) juga membandingkan kefektifan model pembelajaran Collaborative-Cooperative dengan yang konvensional. Berdasarkan penelitian yang dilakukan (Kazemi \& Ghoraishi, 2012), (Simorangkir, 2018), dan (Harianto et al., 2020), sama-sama menyimpulkan bahwa pembelajaran yang berpusat pada dosen kurang efektif, Pembelajaran konvensional ini berpusat pada dosen. Pembelajaran yang berpusat pada pendidik (dosen) ini tidak lagi dapat diterapkan pada pembelajaran jaman sekarang. Mahasiswa hanya pasif mendapatkan materi yang diberikan pendidik (guru/dosen), tidak akan dapat membuat mahasiswa berpikir kritis. Siswa yang aktif pada kegiatan pembelajaran akan dapat peningkatkan hasil belajar (Lakkas, 2018). Menurut (Dadri, Dantes, \& Gunamantha, 2019), segala kegiatan belajar mengajar di 
kelas, hendaknya pendidik (guru/dosen) harus selalu memunculkan inovasiinovasi pembelajaran dengan menerapkan model-model pembelajaran daring yang lebih variatif namun tetap sesuai dengan tujuan pembelajaran matematika. Karena pada masa pandemik ini hanya dapat menggunakan model pembelajaran daring, maka sebaik mungkin dirancang sehingga mahasiswa tetap aktif. Saya sebelumnya menerapkan model pembelajaran daring menggunakan grup WhatsApp dengan beberapa aturan yang diberlakukan, yang saya tulis di artikel saya (Susilowati, 2020).

Model pembelajaran daring menggunakan grup WhatsApp tipe II yang diterapkan sebelumnya di mata kuliah Struktur Aljabar (Susilowati, 2020) memang sudah cukup baik, namun pada saat evaluasi dan masukan mahasiswa, masih saja ditemukan kelemahan. Sehingga saya menyempurnakan dengan mengatasi kelemahan tersebut, dan muncullah model pembelajaran yang berbeda dengan yang sebelumnya dengan mengedepankan lebih banyak keunggulan. Model pembelajaran yang baru tersebut dinamakan model pembelajaran daring melalui Grup WhatsApp tipe III.

Langkah-langkah model pembelajaran daring melalui Grup WhatsApp tipe III yang berbeda dari tipe sebelumnya adalah sebagai berikut. (1) Pada model pembelajaran daring menggunakan grup WhatsApp tipe III ini, dosen langsung memberikan pertanyaan menyangkut indikator yang harus diketahui oleh mahasiswa. Jadi di sini dosen tidak menjelaskan panjang lebar, namun hanya memancing dengan menggunakan pertanyaan yang searah dengan indikator yang harus dipahami oleh mahasiswa. (2) Dosen dan mahasiswa dapat menjawab atau menerangkan jawaban pertanyaan dengan menggunakan video jika diperlukan agar lebih jelas. (3) Untuk mengontrol apakah mahasiswa tersebut mengerjakan secara berkelompok dan semua anggota kelompok paham, dosen mengadakan kontrol dengan mengadakan kuis di pertemuan berikutnya setelah tugas dikumpulkan. Pertanyaan kuis seputar tugas kelompoknya yang dikumpulkan. Kontrol dilakukan agar soal tugas yang dikerjakan benar-benar dimengerti semua anggota kelompok, jawaban kuis diberikan pada awal dan akhir pertemuan berikutnya dengan mengirimkan video oleh mahasiswa yang ditunjuk acak.

Berdasarkan (Nirfayanti \& Nurbaeti, 2019), media pembelajaran menggunakan Google Classroom memiliki pengaruh terhadap motivasi belajar mahasiswa. Pengaruh baik juga diperoleh dari penerapan aplikasi Google Classroom dalam pembelajaran (Darmawan, 2019). Dengan demikian, saya mencoba menerapkan model pembelajaran daring dengan menggunakan aplikasi Google Classroom di kelas lain.

Langkah-langkah model pembelajaran dengan menggunakan Google Classroom sebagai berikut. (1) Pada jam perkuliahan yang disepakati bersama, dosen mengeshare materi di Google Classroom. (2) Mahasiswa dipersilakan dosen untuk bertanya materi yang dibagikan. Pada langkah 2 ini, dosen 
ingin mengetahui kemampuan mahasiswa dalam belajar mandiri. (3) Pada minggu-minggu tertentu, dosen memberikan tugas lewat Google Classroom yang tidak perlu dikumpulkan pada Google Classroom juga. Namun disediakan forum diskusi untuk tugas yang diberikan.

Berdasarkan banyaknya penelitian yang menyimpulkan pengaruh baik dalam penerapan kedua aplikasi, yaitu WhatsApp dan Google Classroom, saya akhirnya termotivasi untuk meneliti ada tidaknya perbedaan antara nilai rata-rata model pembelajaran daring menggunakan grup WhatsApp dan menggunakan Google Classroom terhadap hasil belajar mahasiswa angkatan 2019 namun pada mata kuliah yang berbeda yaitu Kalkulus I.

Tujuan utama diadakan penelitian ini adalah (1) mengetahui ada tidaknya perbedaan antara nilai rata-rata di kelas yang diterapkan model pembelajaran daring menggunakan grup WhatsApp dan menggunakan Google Classroom terhadap hasil belajar matematika mahasiswa prodi Pendidikan Matematika angkatan 2019 pada mata kuliah Kalkulus I dan (2) mengetahui manakah model pembelajaran daring yang lebih baik di antara model pembelajaran daring menggunakan grup WhatsApp dan menggunakan Google Classroom terhadap hasil belajar matematika mahasiswa prodi Pendidikan Matematika angkatan 2019 pada mata kuliah Kalkulus I.

\section{METODE PENELITIAN}

Penelitian ini termasuk pada kategori penelitian eksperimen. Dalam penelitian ini, desain yang digunakan adalah Posttest -Only Comparison Group Designs. Posttest -Only Comparison Group Designs tidak menerapkan pretest di awal pembelajaran. Dalam riset ini, saya memutuskan memakai dua kelas sebagai kelas eksperimen yaitu kelas 2019 A dan kelas 2019 C, yang mana kelas 2019 A sebagai kelas eksperimen I dan kelas 2019 C sebagai kelas eksperimen II, yang digunakan sebagai obyek penelitian.

\begin{tabular}{lll}
\hline Grup & Perlakuan/Treatment & Posttest \\
\hline $\mathrm{E}_{1} \longrightarrow \mathrm{O}_{1} \longrightarrow$ & $\mathrm{O}_{1}$ \\
$\mathrm{E}_{2} \longrightarrow$ & $\mathrm{X}_{2} \longrightarrow$ & $\mathrm{O}_{2}$ \\
\hline \multicolumn{4}{c}{ Gambar 1. Desain Penelitian }
\end{tabular}

Adapun sampel dari penelitian ini adalah mahasiswa angkatan 2019 A dan C Prodi Pendidikan Matematika Universitas PGRI Adi Buana Surabaya. Pada penelitian ini, saya mengasumsikan bahwa hasil belajar berupa nilai (Ujian Tengah Semester) dari mahasiswa angkatan 2019 Universitas PGRI Adi Buana Surabaya Tahun Ajaran 2019/2020 memiliki hubungan dengan model pembelajaran daring menggunakan Grup WhatsApp dengan model pembelajaran daring melalui Google Classroom dan hipotesis bahwa adanya perbedaan hasil belajar mahasiswa pada mata kuliah Kalkulus I menerapkan kedua model pembelajaran tersebut. Demi mengetahui hubungan antara kedua variabel tersebut maka saya menggunakan teknik random sampling sederhana. Pada riset kali ini, yang dijadikan peubah bebas yaitu model pembelajaran daring menggunakan grup WhatsApp dan model pembelajaran 
daring menggunakan Google Classroom yang selanjutnya pada penelitian ini dikatakan sebagai $X_{1}$ dan $X_{2}$. Dalam riset ini, yang bertindak sebagai variabel dependen adalah hasil belajar/nilai yang selanjutnya pada riset ini dikatakan sebagai variabel $\mathrm{Y}$.

Teknik penyebaran tes pada penelitian ini untuk memperoleh data, dengan memberikan post test berupa Ujian Tengah Semester yang dimanfaatkan untuk menghimpun data nilai/ hasil belajar matematika mahasiswa setelah pemberian treatment model pembelajaran mata kuliah Kalkulus I dengan menggunakan model pembelajaran daring menggunakan grup WhatsApp dan menggunakan Google Classroom. Pada penelitian ini, pengujian validitas instrumen yang dimanfaatkan, mempergunakan validitas pakar dan menghitungnya memakai rumus hitung Pearson Product Moment. Satu diantara rumus yang dimanfaatkan dalam proses pengukuran kestabilan butiran soal/uji reliabilitas yang berupa isian adalah menghitung mempergunakan rumus Cronbach Alpha ( $\alpha$ ).

Penelitian ini dianalisis secara kuantitatif melalui stastistik deskriptif dan statistik inferensial. Statistik deskriptif ini terdiri atas (1) menghitung rata-rata untuk setiap variabel, (2) menghitung standar deviasi dari nilai yang diperoleh dari kelas eksperimen dan kelas kontrol, dan (3) tingkat pemahaman terhadap materi.

Apabila dilihat dari sudut pandang statistik inferensial, teknik analisis yang dipakai untuk tahu berapa koefisien dari perbedaan antara dua buah distribusi data yaitu dengan memakai analisis uji-t
(t-Test). Uji prasyarat diperlukan sebelum dilaksanakannya uji-t, yaitu diharuskan dilaksanakan uji homogenitas dan uji normalitas terlebih dahulu. Uji homogenitas yang digunakan menggunakan uji F. Uji normalitas menggunakan uji Liliefors karena jumlah data yang digunakan kurang dari 30 orang. Data yang diperoleh merupakan data berdistribusi normal, tetapi tidak homogen, maka analisis uji - $\mathrm{t}$ yang digunakan $t$ test: two-sample assuming unequal variances one tail test.

Proses uji hipotesis dimanfaatkan agar diketahui hipotesa sementara ditolak atau diterima dirumuskan sebagai hipotesis penelitian berikut.

Keterangan:

$$
\begin{aligned}
& H_{0}: \mu_{1} \leq \mu_{2} \\
& H_{1}: \mu_{1}>\mu_{2}
\end{aligned}
$$

$H_{0}$ : Rata-rata hasil belajar mata kuliah Kalkulus I pada mahasiswa prodi Pendidikan Matematika Universitas PGRI Adi Buana Surabaya dengan menggunakan model pembelajaran daring menggunakan Grup WhatsApp sama dengan atau lebih kecil daripada rata-rata hasil belajar mata kuliah Kalkulus I menggunakan model pembelajaran daring menggunakan Google Classroom.

$H_{1}$ : Rata-rata hasil belajar mata kuliah Kalkulus I pada mahasiswa prodi Pendidikan Matematika Universitas PGRI Adi Buana Surabaya dengan Menggunakan model pembelajaran daring menggunakan Grup WhatsApp lebih besar dibandingkan ratarata hasil belajar mata kuliah Kalkulus I menggunakan model pembelajaran daring menggunakan Google Classroom.

$\mu_{1}$ : Rata-rata hasil belajar mata kuliah Kalkulus I pada mahasiswa yang diajar dengan model pembelajaran daring menggunakan Grup WhatsApp (kelas eksperimen I).

$\mu_{1}$ : Rata-rata hasil belajar mata kuliah Kalkulus I pada mahasiswa yang diajar dengan model pembelajaran daring menggunakan Google Classroom. (kelas eksperimen II). 
Kriteria pengujian, jika pada taraf $5 \%$ diperoleh nilai $\mathrm{t}$ hitung $<\mathrm{t}$ tabel $\left(t_{e}<t_{r}\right)$, maka $\mathrm{H}_{0}$ diterima. Sebaliknya jika pada taraf nilai $\mathrm{t}$ hitung $>\mathrm{t}$ tabel $\left(t_{e}>t_{r}\right)$ maka $\mathrm{H}_{0}$ ditolak.

\section{HASIL DAN PEMBAHASAN}

\section{Hasil Posttest Kelompok Eksperimen I}

Berdasarkan data yang diperoleh yaitu berupa nilai pada kelompok eksperimen I, dapat menghasilkan intrepertasi statistik deskriptif sebagaimana diuraikan di bawah ini.

1. Saya dapat dihitung nilai mean posttest kelompok eksperimen I sebagai berikut.

$$
\bar{X}=\frac{\sum_{i=1}^{29} f_{i} x_{i}}{29}=\frac{2117}{29}=73
$$

2. Saya akan menghitung standar deviasi berdasarkan data yang diperoleh pada hasil posttest kelompok eksperimen I maka standar deviasi sampel adalah

$$
\begin{aligned}
S t d D v S & =\sqrt{\frac{\sum_{i=1}^{29} f_{i}\left(x_{i}-\bar{X}\right)^{2}}{29-1}} \\
& =11.74
\end{aligned}
$$

Standar deviasi digunakan untuk mengetahui apakah sampel data yang diambil mewakili seluruh populasi. Apabila dihitung dari data posttest kelas eksperimen I maka mean hasil belajar mahasiswa menerapkan pembelajaran daring menggunakan grup WhatsApp adalah 73 dengan standar deviasi sampel sebesar 11,74. Hal ini berarti cukup besar sebaran kelompok data terhadap rataratanya atau cukup heterogen suatu kelompok data. Nilai maksimum yang diperoleh pada kelas eksperimen I adalah
96 dan nilai minimum yang diperoleh pada kelas eksperimen I adalah 30.

Apabila nilai posttest mahasiswa dikelompokkan dalam kategori sangat rendah, rendah, sedang, tinggi, dan sangat tinggi, maka akan didapat frekuensi serta presentase setelah dilakukan posttest yang dimasukkan ke dalam kategori kelompok. Menurut hasil nilai posttest terdapat satu orang $(3.45 \%)$ mahasiswa yang dikategorikan pada kategori sangat rendah, satu orang (3.45\%) mahasiswa yang dikategorikan pada kategori rendah, pada kategori sedang terdapat lima orang (17.24\%), pada kategori tinggi terdapat tujuh belas orang (58.62\%) dan sebanyak lima orang(17.24\%) berada pada kategori sangat tinggi.

Tabel 1. Nilai Statistik Deskriptif Hasil Posttest pada Kelompok Eksperimen I

\begin{tabular}{cc}
\hline Statistik & $\begin{array}{c}\text { Nilai Statistik } \\
\text { Posttest }\end{array}$ \\
\hline Nilai terendah & 30 \\
Nilai tertinggi & 96 \\
Nilai rata-rata/mean & 73 \\
Standar deviasi & 11.74 \\
\hline
\end{tabular}

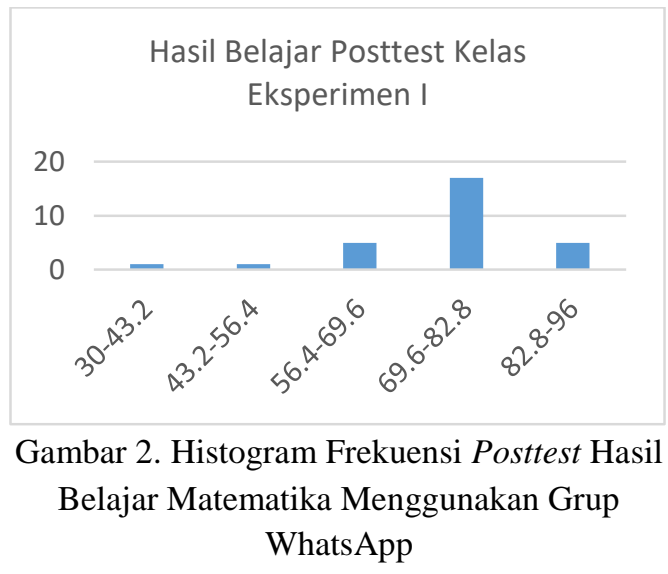


Menurut hasil perhitungan Tabel 1, hasil nilai posttest pada pembelajaran daring menggunakan grup WhatsApp, rentang nilai dari nilai maksimum ke minimum sangat jauh. Keberagaman nilai posttest yang terjadi lumayan beragam jika dilihat dari standar deviasi.

\section{Hasil Posttest Kelompok Eksperimen II}

Berdasarkan data yang diperoleh berupa nilai dari kelompok eksperimen II, dapat menghasilkan intrepertasi statistik deskriptif sebagaimana diuraikan di bawah ini.

1. Pertama, dapat dihitung nilai mean posttest kelompok eksperimen II sebagai berikut.

$$
\bar{X}=\frac{\sum_{i=1}^{16} f_{i} x_{i}}{16}=\frac{1088}{16}=68
$$

2. Kita akan menghitung standar deviasi berdasarkan data yang diperoleh pada hasil posttest kelompok eksperimen II maka setelah dihitung menggunakan Microsoft Excel, standar deviasi sampel adalah

$$
\begin{aligned}
S t d D v S & =\sqrt{\frac{\sum_{i=1}^{16} f_{i}\left(x_{i}-\bar{X}\right)^{2}}{16-1}} \\
& =14.15
\end{aligned}
$$

Apabila dihitung dari data posttest kelas eksperimen II maka mean hasil belajar mahasiswa menerapkan pembelajaran daring menggunakan Google Classroom adalah 68 dengan standar deviasi sampel sebesar 14.15. Hal ini berarti sebaran kelompok data terhadap rata-ratanya cukup besar atau cukup heterogen suatu kelompok data. Nilai maksimum yang diperoleh pada kelas eksperimen I adalah 87 dan nilai minimum yang diperoleh pada kelas eksperimen II adalah 48.

Menurut hasil nilai posttest terdapat enam orang (37.25\%) mahasiswa yang dikategorikan pada kategori sangat rendah, tidak ada ( $0 \%)$ mahasiswa yang dikategorikan pada kategori rendah, pada kategori sedang terdapat dua orang (18.75\%), pada kategori tinggi terdapat tiga orang $(18.75 \%)$ dan sebanyak lima orang $(31.25 \%)$ berada pada kategori sangat tinggi.

Tabel 3. Nilai Statistik Deskriptif Hasil Posttest pada Kelompok Eksperimen II

\begin{tabular}{cc}
\hline Statistik & $\begin{array}{c}\text { Nilai Statistik } \\
\text { Posttest }\end{array}$ \\
\hline Nilai terendah & 48 \\
Nilai tertinggi & 87 \\
Nilai rata-rata/mean & 68 \\
Standar deviasi & 14.15 \\
\hline
\end{tabular}

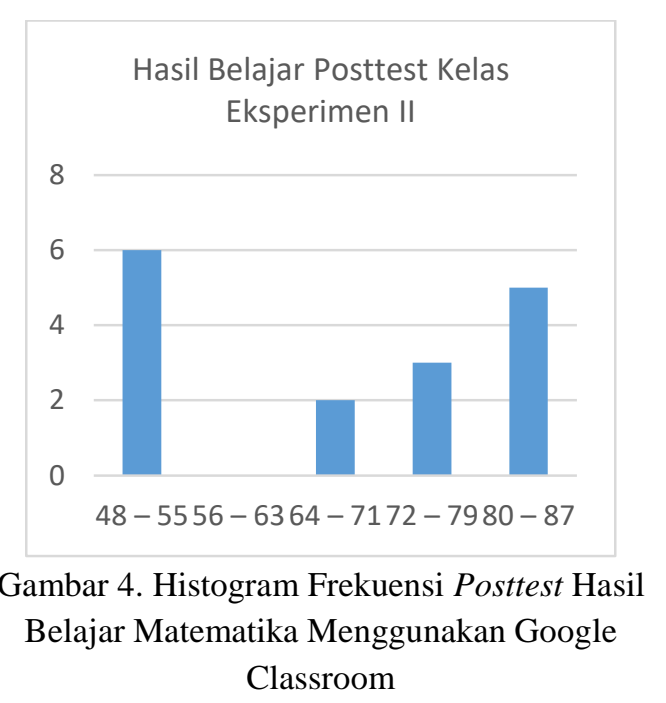

Menurut hasil perhitungan di atas, hasil nilai posttest pada pembelajaran daring menggunakan Google Classroom, rentang nilai dari nilai maksimum ke minimum tidaklah sejauh rentang nilai dari hasil posstest pada kelas yang menggunakan Grup WhatsApp. Nilai 
terendah pada kelas eksperimen I masih lebih rendah dibandingkan kelas eksperimen II. Namun, nilai tertinggi kelas eksperimen I masih lebih tinggi dibandingkan kelas ekperimen II. Jika kita menilik dari rata rata/mean antara kelas eksperimen I dan kelas eksperimen II, dapat terlihat kelas eksperimen I dengan jumlah mahasiswa 29 orang lebih tinggi dibandingkan nilai rata rata/mean kelas ekperimen II yang terdiri dari 16 orang mahasiswa. Keberagaman nilai posttest pada kelas eksperimen II jika dibandingkan dengan pada kelas eksperimen I yang terjadi jauh lebih beragam kelas eksperimen I jika dilihat dari standar deviasi masing masing kelas eksperimen.

Apabila kita membandingkan nilai posttest yang diperoleh dari kedua kelas eksperimen dari melihat dua histogram yang disajikan sebelumnya, mahasiswa pada kelas eksperimen I yang mendapat nilai yang termasuk pada kategori sedang, rendah, dan sangat rendah (dibawah nilai 69.6) hanya 7 dari 29 orang. Hal ini jika dipresentase sekitar $24.13 \%$. Presentase tersebut bisa dibilang cukup kecil jika dibandingkan presentase mahasiswa yang masuk kategori sedang, rendah, sangat rendah (dibawah 71) pada kelas eksperimen II sebesar 50\%. Dengan demikian dalam kasus ini berdasarkan analisis statistik deskriptif, pembelajaran daring menggunakan grup WhatsApp lebih mudah dipahami oleh mahasiswa dibandingkan menggunakan Google Classroom.

Selanjutnya, saya akan menganalisis data dengan analisis statistik inferensial. Langkah pertama yang dilakukan adalah melakukan uji normalitas dengan tujuan mengetahui apakah data sampel yang digunakan berdistribusi normal. Dalam penelitian ini uji normalitas menggunakan metode Liliefors yang dihitung menggunakan Microsoft Excel. Hasil $\mathrm{L}_{\text {hitung }}=0.139488<0.25=\mathrm{L}_{\text {tabel}}$, sehingga data sampel pada kelas eksperimen I berdistribusi normal. Sedangkan, $\mathrm{L}_{\text {hitung }}=0.202451<0.25=\mathrm{L}_{\text {tabel}}$, sehingga data sampel pada kelas eksperimen II berdistribusi normal.

Langkah berikutnya adalah mengecek apakah data dari dua kelas eksperimen tersebut homogen atau tidak. Untuk mengecek hal tersebut, pada penelitian ini menggunakan uji $\mathrm{F}$ dengan Microsoft Excel.

\begin{tabular}{|l|r|r|}
\hline \multicolumn{3}{|l|}{ F-Test Two-Sample for Variances } \\
\hline & Variable 1 & Variable 2 \\
\hline Mean & 73.62069 & 67.8125 \\
\hline Variance & 169.1724 & 214.0292 \\
\hline Observations & 29 & 16 \\
\hline df & 28 & 15 \\
\hline F & 0.790418 & \\
\hline P(F<=f) one-tail & 0.286042 & \\
\hline F Critical one-tail & 0.489939 & \\
\hline
\end{tabular}

Gambar 5. Keluaran Uji F

Kriteria pengujian yang dihasilkan dalam penelitian ini ternyata $F_{\text {hitung }}=$ $0.790418>0.489939=F_{\text {tabel }}$ pada taraf nyata dengan $F_{\text {tabel }}$ diperoleh dari distribusi $\mathrm{F}$ dimana derajat kebebasan setiap data harus cocok dengan $d k$ pembilang dan $d k$ penyebut pada taraf $\alpha=0,05$. Hal ini mengakibatkan data yang ditetapkan sebagai populasi penelitian dari kedua kelas eksperimen bersifat tidak homogen. Dengan demikian, langkah selanjutnya untuk menganalisis data ini dapat dilanjutkan ke uji- $t$ dengan rumus separated 
variance. Ketika kita menggunakan Microsoft Excel maka pada pilihan data analisis, kita pilih uji t-test: two-sample assuming unequal variances.

Tampilan pada Microsoft Excel ketika dilakukan uji t-tes: two-sample assuming unequal variances terhadap data yang dijadikan sampel penelitian, yaitu nilai UTS kelas 2019 A dan 2019 C diperlihatkan pada Gambar 6.

\begin{tabular}{|l|r|r|}
\hline \multicolumn{3}{|c|}{$\mathrm{t}$-Test: Two-Sample Assuming Unequal Variances } \\
\hline & Skor Posttest I & Skor Posttest II \\
\hline Mean & 73.62068966 & 67.8125 \\
\hline Variance & 169.1724138 & 214.0291667 \\
\hline Observations & 29 & 16 \\
\hline Hypothesized Mean Dif & 0 & \\
\hline$d f$ & 28 & \\
\hline$t$ Stat & 1.325174591 & \\
\hline$P(T<=t)$ one-tail & 0.097912952 & \\
\hline$t$ Critical one-tail & 1.701130934 & \\
\hline$P(T<=t)$ two-tail & 0.195825905 & \\
\hline$t$ Critical two-tail & 2.048407142 & \\
\hline
\end{tabular}

Gambar 6. Keluaran Uji t-test

Jika melihat Tabel 6 , thitung $=$ $1.325174591<1.701130934=\mathrm{t}_{\text {tabel }}$, maka $\mathrm{H}_{0}$ diterima. Jadi simpulkan tidak ada perbedaan yang signifikan antara rata-rata hasil belajar mata kuliah Kalkulus I pada mahasiswa prodi Pendidikan Matematika Universitas PGRI Adi Buana Surabaya dengan menggunakan model pembelajaran daring menggunakan Grup WhatsApp dan rata-rata hasil belajar mata kuliah Kalkulus I menggunakan model pembelajaran daring menggunakan Google Classroom.

Tahap pertama, kita perhatikan pada hasil analisis yang dilakukan menggunakan statistik deskriptif. Apabila kita membandingkan nilai posttest yang diperoleh dari kedua kelas eksperimen dari melihat dua histogram yang disajikan sebelumnya, mahasiswa pada kelas eksperimen I yang mendapat nilai yang termasuk pada kategori sedang, rendah dan sangat rendah (di bawah nilai 69.6) hanya 7 dari 29 orang. Hal ini jika dipresentasekan sekitar 24.13\%. Presentase tersebut bisa dibilang cukup kecil jika dibandingkan presentase mahasiswa yang masuk kategori sedang, rendah, sangat rendah (dibawah 71) pada kelas eksperimen II sebesar 50\%. Dengan demikian dalam kasus ini berdasarkan analisis statistik deskriptif, pembelajaran daring menggunakan grup WhatsApp lebih mudah dipahami oleh mahasiswa dibandingkan menggunakan Google Classroom.

Selanjutnya, berdasarkan uraian analisis data menggunakan statistik inferensial pada bab sebelumnya, kita sudah mendapatkan keputusan yang didasari hasil uji t. Pada hasil t-test: two sample assuming unequal variances, disimpulkan tidak ada perbedaan yang signifikan antara rata-rata hasil belajar mata kuliah Kalkulus I pada mahasiswa prodi Pendidikan Matematika Universitas PGRI Adi Buana Surabaya dengan menggunakan model pembelajaran daring menggunakan Grup WhatsApp dan rata-rata hasil belajar mata kuliah Kalkulus I menggunakan model pembelajaran daring menggunakan Google Classroom. Namun jika dilihat rata-rata/mean dari nilai UTS antara kelas eksperimen I dan kelas eksperimen II, terlihat bahwa mean dari nilai UTS pada kelas eksperimen I yang menggunakan grup WhatApps dalam pembelajaran lebih tinggi dari nilai UTS pada kelas eksperimen II. Mean pada kelas ekperimen I adalah 73.62068966 (ketika dicari menggunakan teknik statistik inferensial) dan 73 (ketika dicari 
menggunakan teknik statistik deskriptif). Sedangkan mean pada kelas ekperimen II adalah 67,8125 (ketika dicari menggunakan teknik statistik inferensial) dan 68 (ketika dicari menggunakan teknik statistik deskriptif). Berdasarkan (Widhiarso, 2015), seperti bertolak belakang antara hasil uji t dengan nilai mean yang diperoleh kedua kelas eksperimen. Meskipun kelas ekperimen I mempunyai mean yang lebih tinggi dari kelas ekperimen II, yang artinya hasil belajar mahasiswa di kelas ekperimen I lebih bagus dari kelas ekperimen II. Akibatnya, bisa dikatakan model pembelajaran daring menggunakan grup WhatsApp lebih baik dari model pembelajaran menggunakan Google Classroom. Namun, (Widhiarso, 2015) menjelaskan kasus seperti ini terjadi karena pada selisih mean antara dua kelas eksperimen sangat tipis yaitu antara 67,8125 dan 73.62068966. Sehingga disimpulkan pada saat uji t, tidak ada perbedaannya yang signifikan.

Dari kedua teknik analisis statistik yang digunakan pada penelitian ini, dapat ditarik kesimpulan bahwa model pembelajaran daring menggunakan grup WhatsApp sedikit lebih baik dibandingkan menggunakan Google Classroom. Pada kasus lain, mungkin saja berbeda hasil meskipun sama-sama membandingkan kedua kelas ekperimen menggunakan Grup WhatsApp dan Google Classroom. Pada saat, pembelajaran dilaksanakan menggunakan Google Classroom. Hal ini juga tidak lain dikarenakan sistem/aturan pembelajaran yang diterapkan ketika menggunakan Grup WhatsApp dan menggunakan Google Classroom.
Pada saat menggunakan Google Classroom, mahasiswa dicoba untuk diberi kebebasan dalam mengerjakan tugas. Tugas memang tidak dikumpulkan dan hanya diberikan ruang diskusi terkait tugas yang diberikan. Pada kelas menggunakan Google Classroom, dibebaskan tidak mengumpulkan dan diberikan forum diskusi, diharapkan dapat belajar mandiri. Ternyata hal ini tidak berdampak baik pada mahasiswa karena sebagian kecil saja yang menanggapi forum diskusi dan mengerjakan tugas.

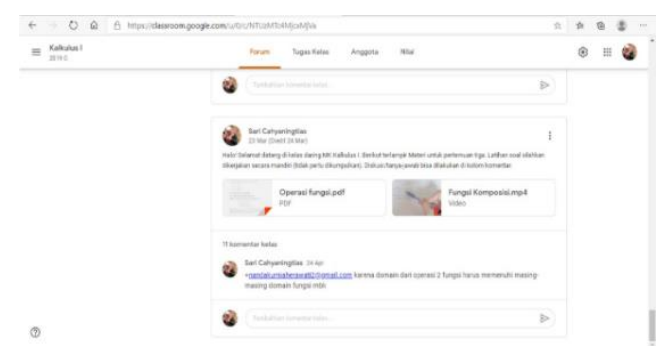

Gambar 7. Tampilan Google Classroom

Sedangkan pada saat menggunakan grup WhatsApp, mahasiswa ditugaskan untuk mengerjakan tugas hampir setiap minggu, walau tugas dikerjakan secara berkelompok. Namun, pada minggu berikutnya dosen mengecek dengan memanggil salah satu NIM secara acak, kemudian meminta mengerjakan salah satu soal dari yang kemarin ditugaskan dengan menggunakan video. Video tersebut kemudian dikirimkan ke grup WA. Pada kelas yang menggunakan grup WhatsApp dituntut secara halus untuk mengerjakan meski secara kelompok. Karena setiap pertemuan berikutnya, dosen memanggil secara acak mahasiswa untuk membuat video pengerjaan tugas. Dari segi kognitif, mahasiswa dapat bersikap kritis, kreatif, 
dan mampu mentrasfer ilmu ke teman sekelompok. Dengan demikian, mahasiswa lebih terlatih menghadapi soal dan siap mengerjakan ujian.

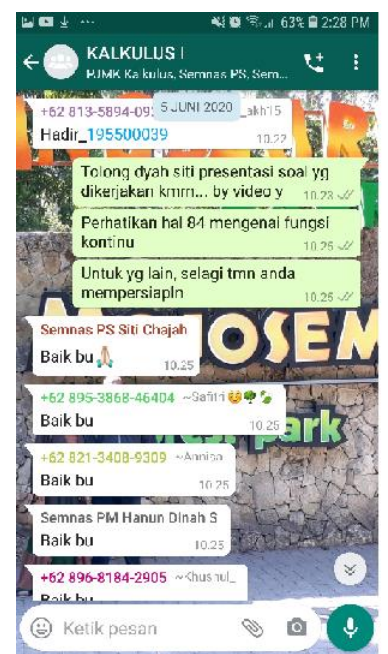

Gambar 8. Tampilan Grup WhatsApp

Dari segi aturan/sistem tugas ini yang ibaratnya jauh berbeda antara kelas yang menggunakan Google Classroom dan menggunakan grup WhatsApp, ternyata memberikan hasil yang berbeda. Hasil dapat dilihat dari capaian kedua kelas eksperimen pada nilai UTS masing-masing. Mengapa saya mengatakan aturan tugas ini menjadi salah satu faktor penentu keberhasilan di antara dua model pembelajaran daring yang digunakan? Karena tugas yang diberikan setiap dosen, sebenarnya dapat menjadi salah satu bentuk evaluasi pemahaman yang dicapai oleh mahasiswa. Aturan penugasan pada kelas yang menggunakan Google Classroom bisa saja hanya dikerjakan sebagian mahasiswa dan ditanggapi diskusinya oleh sebagian juga. Hal ini karena ada kelonggaran peraturan yang diberikan, yaitu tidak dikumpulkan dan tidak ada poin yang diperhitungkan pada nilai tugas bagi mahasiswa yang bertanya pada forum diskusi yang disediakan. Akibatnya, hanya bisa dimungkinkan hanya sebagian mahasiswa yang terlatih mengerjakan soal. Padahal mata kuliah Kalkulus I ini diperlukan banyak sekali latihan soal karena modifikasi suatu soal dalam Kalkulus ini sangat variatif. Mahasiswa tanpa latihan yang banyak, kemungkinan kecil akan berhasil pada saat ujian.

Pada sisi lain, kelas yang menggunakan grup WhatsApp diwajibkan mengerjakan soal pada minggu berikutnya melalui video yang dikirim ke grup WhatsApp. Mengapa dikatakan diwajibkan? Karena pemilihan mahasiswa yang mengerjakan salah satu soal tugas minggu sebelumnya, dipilih secara acak oleh dosen. Akibatnya, mau tidak mau, mahasiswa harus memahami setiap butir soal yang dikerjakan pada tugas minggu sebelumnya. Dampak positif yang terjadi dan diharapkan oleh dosen, mahasiswa dengan aturan/sistem tugas seperti ini, dapat digunakan untuk mencicil belajar setiap minggu. Dengan demikian, mahasiswa tersebut sudah siap lebih awal untuk menghadapi ujian yang mungkin bahan yang dipelajari tidak sedikit. Apalagi mata kuliah Kalkulus I ini tidak bisa ditaklukkan hanya dengan menghafal materi yang diberikan dosen, yang porsinya terbatas.

Pemberian tugas pun antara kelas yang menggunakan Grup WhatsApp dan Google Classroom berbeda. Tugas yang diberikan pada kelas yang menggunakan Google Classroom bersifat individu sedangkan kelas yang menggunakan Grup WhatsApp dikerjakan secara berkelompok. Hal ini diharapkan akan tumbuh kerjasama yang solid antar 
anggota kelompok. Setiap anggota akan bahu-membahu menyelesaikan tugas. Bagi mahasiswa yang lebih pandai dapat menyalurkan ilmunya ke anggota kelompok yang kurang pandai sebagaimana telah disampaikan oleh (Harianto et al., 2020), karena adanya tuntutan dosen untuk membuat video pengerjaan salah satu tugas secara acak pada minggu berikutnya. Sehingga siapapun dalam kelompok itu harus siap. Selain itu, pemberian tugas secara grup dapat meningkatkan cara berpikir kritis dan kreatif pada mahasiswa seperti diungkapkan oleh (Schnittka \& Schnittka, 2016), karena adanya diskusi antar anggota kelompok. Diskusi ini dimungkinkan akan muncul pertanyaan antar anggota yang mungkin tidak terpikirkan ketika mahasiswa belajar secara individu.

Selain itu, penggunaan Grup WhatsApp jauh lebih ekonomis jika dibandingkan Google Classroom sebagaimana telah diulas pada penelitian ( $\mathrm{La}$ Hanisi, Risdiany, Dwi Utami, \& Sulisworo, 2018). Ekonomis ini akan membuat mahasiswa dapat lebih mudah mengikuti jika diadakan diskusi yang waktunya satu minggu untuk satu topik. Mahasiswa tidak terganggu dengan kemungkinan keterbatasan mereka terhadap kuota internet.

Banyak mahasiswa yang lebih memilih grup WhatsApp karena tidak membutuhkan banyak kuota internet. Akibatnya, mereka dapat mengikuti pembelajaran sepanjang hari terutama untuk pembelajaran yang diberi waktu pembahasan topik satu minggu misalnya, tanpa takut kuota habis.

\section{PENUTUP}

Berdasarkan hasil dan pembahasan di atas dapat disimpulkan bahwa model pembelajaran daring menggunakan Grup WhatsApp sedikit lebih baik dibandingkan menggunakan Google Classroom dengan memperhatikan teknis/sistem yang diberlakukan selama pembelajaran berlangsung. Meskipun kesimpulan dari hasil uji $t$ two-samples assumming variances tidak ada perbedaan signifikan rata-rata hasil belajar antara kelas yang menerapkan model pembelajaran daring menggunakan Grup WhatsApp sedikit lebih baik dibandingkan menggunakan Google Classroom. Ada sedikit perbedaan ini jika ditilik dari hasil analisis statistik deskriptifnya. Sedikit keunggulan yang dicapai oleh model pembelajaran daring melalui Grup WhatsApp ini, dapat diperoleh karena aturan atau sistem yang diterapkan pada kelas eksperimen. Salah satunya pada aturan/sistem pemberian tugas yang berbeda antara kelas yang menggunakan Grup WhatsApp dan Google Classroom.

\section{DAFTAR PUSTAKA}

Amijaya, L. S., Ramdani, A., \& Merta, I. W. (2018). Effect of Guided Inquiry Learning Model Towards Student Learning Outcomes and Critical Thinking Ability. J. Pijar MIPA, 13(2), 94-99. https://doi.org/10.29303/jpm.v13.i 2.468

Dadri, P. C. W., Dantes, N., \& Gunamantha, I. M. (2019). Pengaruh Model Pembelajaran Kooperatif Tipe NHT terhadap Kemampuan Berpikir Kritis dan Hasil Belajar Matematika Siswa Kelas V SD Gugus III Mengwi, 3(2), 84-93. 
Darmawan, Y. (2019). Penggunaan Aplikasi Google Classroom Dalam Upaya Meningkatkan Hasil Belajar Matematika Pada Siswa Kelas X Sma Jurusan Ips. Prodi Pendidikan Matematika Universitas Muhammadiyah Surakarta.

Harianto, G., Rusijiono, R., Masitoh, S., \& Setyawan, W. (2020). Collaborative-Cooperative Learning Model To Improve Theology Students' Characters: Is It Efective? Jurnal Cakrawala Pendidikan, 39(2), 409-421. https://doi.org/10.21831/cp.v39i2. 31272

Kazemi, F., \& Ghoraishi, M. (2012). Comparison of Problem-Based Learning Approach and Traditional Teaching on Attitude, Misconceptions and Mathematics Performance of University Students. Procedia - Social and Behavioral Sciences, 46, 38523856. https://doi.org/10.1016/ j.sbspro.2012.06.159

La Hanisi, A., Risdiany, R., Dwi Utami, Y., \& Sulisworo, D. (2018). The use of WhatsApp in collaborative learning to improve English teaching and learning process. International Journal of Research Studies in Educational Technology, 7(1). https://doi.org/ 10.5861/ijrset.2018.3004

Lakkas, M. (2018). Pengaruh Model Pembelajaran Kooperatif Terhadap Motivasi Dan Hasil Belajar Siswa Pada Materi Sistem Koloid SMAN 4 Bantimurung Maros. PEMBELAJAR: Jurnal Ilmu Pendidikan, Keguruan, Dan Pembelajaran, 2(1), 12. https://doi.org/10.26858/pembelaj ar.v2i1.4135
Nirfayanti, N., \& Nurbaeti, N. (2019). Pengaruh Media Pembelajaran Google Classroom Dalam Pembelajaran Analisis Real Terhadap Motivasi Belajar Mahasiswa. Proximal, 2(1), 5059. Retrieved from https://ejournal.my.id/proximal/article/vie $\mathrm{w} / 211$

Schnittka, J., \& Schnittka, C. (2016). "Can i drop it this time?" Gender and collaborative group dynamics in an engineering design-based afterschool program. Journal of Pre-College Engineering Education Research, 6(2), 1-24. https://doi.org/10.7771/21579288.1120

Simorangkir, S. J. V. (2018). the Effectiveness of Jigsaw Learning Method Compared To LectureBased Learning in Anatomy Lectures. Jurnal Pendidikan Kedokteran Indonesia: The Indonesian Journal of Medical Education, $\quad 7(2), \quad 118$. https://doi.org/10.22146/jpki.3910 2

Susilowati, E. (2020). Bagaimana Pembelajaran Daring di Tengah Wabah Covid 19 melalui Grup WhatsApp? Jurnal Pendidikan Matematika Raflesia, 05(03), 125.

Sutiarso, S., Coesamin, M., \& Nurhanurawati. (2018). The effect of various media scaffolding on increasing understanding of students' geometry concepts. Journal on Mathematics Education, 9(1), 95-102. https://doi.org/10.22342/jme.9.1.4 291.95-102

Widhiarso, W. (2015). Bab ii uji hipotesis komparatif. 